Revue musicale OICRM

\title{
The Resonance of Debussy for United States Post-Modernists
}

\section{James Briscoe}

Volume 2, numéro 1, 2014

La réception de Debussy au XXe siècle. Incidences, influences et autorité

URI : https://id.erudit.org/iderudit/1055849ar

DOI : https://doi.org/10.7202/1055849ar

Aller au sommaire du numéro

Éditeur(s)

OICRM

ISSN

2368-7061 (numérique)

Découvrir la revue

Citer cet article

Briscoe, J. (2014). The Resonance of Debussy for United States Post-Modernists. Revue musicale OICRM, 2(1), 116-140. https://doi.org/10.7202/1055849ar

\section{Résumé de l'article}

Cette étude s'appuie sur des entretiens réalisés par l'auteur avec des compositeurs américains. Les résultats montrent que Claude Debussy continue à exercer une influence profonde dans la composition musicale aux États-Unis depuis les années 1960. Dans cette optique, on peut mieux circonscrire ce que Debussy a voulu dire en 1895 : «Je travaille à des choses qui ne seront comprises que par les petits-enfants du xxe siècle. » Les compositeurs interviewés pour l'occasion sont Leslie Bassett, William Bolcom, Dave Brubeck, Elliott Carter, John Corigliano, George Crumb, Richard Danielpour, Philip Glass, John Harbison, Tania León, Wynton Marsalis, Pauline Oliveros, Steve Reich, Bright Sheng, Joseph Schwantner, Steven Stucky, Robert Ward et Ellen Taaffe Zwilich. Cinq résonances debussystes restent toujours d'actualité : 1) le fait qu'il a initié une écoute de type multiculturel qui va au-delà des barrières nationales ; 2) le fait qu'il a contribué à alimenter une ouverture d'esprit en fournissant un outillage pour penser la composition ; 3) le fait qu'il a changé radicalement la vision qu'ont les compositeurs de la forme musicale ; 4) le fait qu'il a repris sa place dans le canon musical du xxe siècle par rapport à Schoenberg et Stravinsky ; et 5) le fait qu'il a marqué les compositeurs américains actuels en permettant l'accès à une multitude de choix possibles dans un esprit de cohérence.
Ce document est protégé par la loi sur le droit d'auteur. L'utilisation des services d’Érudit (y compris la reproduction) est assujettie à sa politique d'utilisation que vous pouvez consulter en ligne.

https://apropos.erudit.org/fr/usagers/politique-dutilisation/ 


\title{
The Resonance of Debussy for United States Post-Modernists
}

\author{
James Briscoe
}

\section{Résumé}

Cette étude s'appuie sur des entretiens réalisés par l'auteur avec des compositeurs américains. Les résultats montrent que Claude Debussy continue à exercer une influence profonde dans la composition musicale aux États-Unis depuis les années 1960. Dans cette optique, on peut mieux circonscrire ce que Debussy a voulu dire en 1895 : " Je travaille à des choses qui ne seront comprises que par les petits-enfants $\mathrm{du} \mathrm{Xx}^{\mathrm{e}}$ siècle. » Les compositeurs interviewés pour l'occasion sont Leslie Bassett, William Bolcom, Dave Brubeck, Elliott Carter, John Corigliano, George Crumb, Richard Danielpour, Philip Glass, John Harbison, Tania León, Wynton Marsalis, Pauline Oliveros, Steve Reich, Bright Sheng, Joseph Schwantner, Steven Stucky, Robert Ward et Ellen Taaffe Zwilich. Cinq résonances debussystes restent toujours d'actualité : 1) le fait qu'il a initié une écoute de type multiculturel qui va au-delà des barrières nationales ; 2) le fait qu'il a contribué à alimenter une ouverture d'esprit en fournissant un outillage pour penser la composition ; 3) le fait qu'il a changé radicalement la vision qu'ont les compositeurs de la forme musicale ; 4) le fait qu'il a repris sa place dans le canon musical du $\mathrm{xx}^{\mathrm{e}}$ siècle par rapport à Schoenberg et Stravinsky ; et 5) le fait qu'il a marqué les compositeurs américains actuels en permettant l'accès à une multitude de choix possibles dans un esprit de cohérence.

Mots clés : compositeur américain ; contemporain ; Debussy ; États-Unis ; influence.

\begin{abstract}
This study draws upon interviews with It seeks to show that Claude Debussy continues to exert a presence in contemporary United States composition. It thus can be seen that Debussy already foresaw such a possibility when he wrote in 1908, "I am working on things that will be understood only by our grandchildren in the 20th children." Composers interviewed were Leslie Bassett, William Bolcom, Dave Brubeck, Elliott Carter, John Corigliano, George Crumb, Richard Danielpour, Philip Glass, John Harbison, Tania León, Wynton Marsalis, Pauline Oliveros, Steve Reich, Bright Sheng, Joseph Schwantner, Steven Stucky, Robert Ward, and Ellen Taaffe Zwilich. Five resonances abide from Debussy: 1) that he has instigated multi-cultural listening including across national lines, 2) has contributed to a set of identifiable predispositions or mindsets (forming an "armature" for a composition), 3) has led to a changed attitude toward forming, 4) has superseded Schoenberg and Stravinsky in importance, and 5) has impressed U.S. composers by permitting any realm of possible but necessarily coherent choices.
\end{abstract}

Keywords: American composer; contemporary; Debussy; influence; United States. 
This study seeks to show that Claude Debussy continues to exert a presence in contemporary United States composition. It thus can be seen that Debussy already foresaw such a possibility when he wrote in 1908, "I am working on things that will be understood only by our grandchildren in the 20th children" (Forte 1992, p. 471). In the same year, he spoke in an interview of the potential in the U.S. for the embrace of modernist, multi-cultural hearing:

The distinction of a country like [the United States] is that it imbibes from all sources, and in that way will arrive more quickly than if it struggled into a foreign voice and then groped out of it into its own personality and individual strength - in short, it is less German bound than are the countries who hear little or no other music through chauvinism or antipathies" (Boston Transcript 1908).

For the generation of the American Neo-Classicists, composing from about 1920 to 1950, Virgil Thomson foretold Debussy's impact yet to be fully realized, although he identified with particular insight the procedure of imagining and then structuring:

Among all our musical masters, 1 should say, Claude Debussy was the least weighed upon by the dead hand of formula. Yet neither was he an improviser. This latter art, indeed, among all the compositional techniques, is the one most servile to rules of thumb. Debussy's operation was more thorough. Like any Frenchman building a bridge or cooking a meal, painting a picture or laying out a garden, he felt, he imagined, he reasoned, he constructedand in that order (Thomson [Schmitz] 1950, p. ix-X).

Philip Glass of the present day introduces the thesis of this study, that a Debussy resonance remains active if subtle in the contemporary composer's imagination: "We tend to concentrate on the biggies, like Boulez, Stockhausen, Bartók, and forget other influences which may be subtler but more lasting. Like Debussy. I think about him more now than I ever did" (Glass 1992, p. 270).

PURPOSE

Since about 1960, Debussy's influence has been confirmed in post-modern American composition. This study results from interviews with composers between 2004 and 2011. Let me emphasize two risks that such a study can encounter and state how I have responded. First, I do not seek to prove a point-to-point influence, although as I quote composers, they rather often slip into that rhetoric and I follow for the sake of the dialogue. In general, however, at a distance of nearly 100 years since the composer's death, and considering the convergence of subsequent musical forces, it is unrealistic to do so. Acknowledging that, I can state with certainty that composers recognize Debussy's continuing presence in several distinct ways. And second, no-one can articulate patterns and the interaction of thought and feeling accurately. However, that 21 composers agree on essential matters, and cross reference each other absent "loaded" prompts from me, confirms that broad impacts are in force today. Composers were interviewed from 2004 through 2011. Some were 
interviewed multiple times, and it therefore appears reasonable to cite 2004 for the date of all interviews.

Composers nearly all concur on five resonances abiding from Debussy: 1) that he has instigated multi-cultural listening including across national lines, 2) he has contributed to a set of identifiable predispositions or mindsets (forming an "armature" for a composition), 3) he has led to a changed attitude toward forming, 4) he has superseded Schoenberg and Stravinsky in importance, and 5) he has impressed U.S. composers by permitting any realm of possible but necessarily coherent choices.

The "grandchildren of the 20th century" whom Debussy seemed to foresee, and who in fact evolved, one can characterize as post-modernists in the sense of radical stylistic pluralism. Debussy is a modernist to be sure, a creative artist who senses a mandate of radical change proper to his time, but not one that eschews a continuous, progressive line of development (Botstein 2013). He evolves from the post-tonality of the 1880s mélodies to multi-faced post-tonality of the ballet Jeux and the Études pour piano. But furthermore, Debussy stands as a dominant force compelling individual choices, all valid. Today's United States composer feels fully at liberty to embark on paths she or he finds vital, but she or he insists on communicative musical logic.

The composers considered here, whose creativity spans from about 1960 to the present, refer to Debussy as a model for the plurality they perceive as aesthetic necessity. According to Richard Taruskin, "post-modernism" can be a "notorious catchall." Defining such a term can be nearly impossible, but by reference to another art, architecture, Taruskin finds a succinct frame for postmodernism as pluralism. Postmodernism did not reject the ideas of modernism, but was a convergence of a myriad of ideas (Taruskin 2005, p. 412). For the composers speaking here, that is how Debussy resonates importantly by radical change but one that can refer to the past, reconfiguring it.

\section{Methodology}

The study is based on interviews with 21 foremost United States composers, whose names and representative accomplishments I give in the Table of Composers interviewed. 


\section{Because certain composers were interviewed twice and at varying intervals, and some were interviewed by telephone and some in person, one might cite each interview as "2004 and following."}

Leslie Bassett (1966 Pulitzer Prize for Music, Variations for Orchestra)

William Bolcom (1985 Pulitzer finalist, Songs of Innocence and Experience, a Musical Illumination of the Poems of William Blake; 1988 Pulitzer, 12 New Etudes for Piano)

Dave Brubeck (Library of Congress Living Legend)

Elliott Carter (1960 Pulitzer, Second String Quartet; 1973 Pulitzer, Third String Quartet; 2005 finalist, Dialogues)

John Corigliano (2001 Pulitzer, Symphony no. 2)

George Crumb (1968 Pulitzer, Echoes of Time and the River)

Richard Danielpour (Lifetime Achievement Award, American Academy of Arts and Letters)

Philip Glass (Golden Globe for score of The Truman Show; collaborator with Twyla Tharp, Allen Ginsberg; opera Satyagraha, on Gandhi, 2011 by Occupy Wall Street and performed by the Metropolitan Opera)

John Harbison (1987 Pulitzer, The Flight into Egypt, cantata)

Tania León (founding member Dance Theatre of Harlem, co-founded the Sonidos de las Américas)

Wynton Marsalis (1997 Pulitzer, Blood on the Fields)

Pauline Oliveros (Founder and Director, Deep Listening)

Steve Reich (2003 finalist, Three Tales; 2004 Pulitzer finalist, Cello Counterpoint; 2005 finalist; You Are [variations]; 2009 Pulitzer, Double Sextet)

Bright Sheng (1989 Pulitzer finalist, H'un (Lacerations): In Memoriam 19661976; 1991 finalist, Four Movements for Piano)

Joseph Schwantner (1979 Pulitzer, Afternoons of Infinity)

Steven Stucky (1989 Pulitzer finalist, Concerto for Orchestra; 2005 Pulitzer, Second Concerto for Orchestra),

Joan Tower (1993 Pulitzer finalist, Violin Concerto; first woman recipient of the Grawemeyer Award)

Robert Ward (1962 Pulitzer, The Crucible, opera)

Ellen Taaffe Zwilich (1983 Pulitzer, Symphony no. 1, Three Movements for Orchestra).

Figure 1: Table of composers interviewed, 2004-2011.

Not all will be quoted here, although their main viewpoints are represented. The interviews occurred mostly in person but occasionally by telephone. I started 
by reading a quotation from William W. Austin's 1966 study of the 20th century, an evaluation that appears viable today:

Without necessarily knowing the name of Debussy or the sound of Claire de lune, everyone who grew up hearing and making music in the Western world in the 20th century learns to imagine, clearly or dimly, sounds and sequences of sounds like those that Debussy imagined for the first time (Austin 1966, p. 1-2).

Then without interruption, I heard out the composers' highly varied responses to the Austin, and continued by expanding on points they raised. When the inlet presented itself, I led toward the central themes we can show now. I did not ask, "How did Debussy influence you" because it seemed that would box the response in ways inappropriate to Debussy, although at times composers freely spoke in such terms. Instead, I spoke of continuing suggestion and of whether Debussy's thought continues to resonate, allowing the composer to form her own direction thereupon.

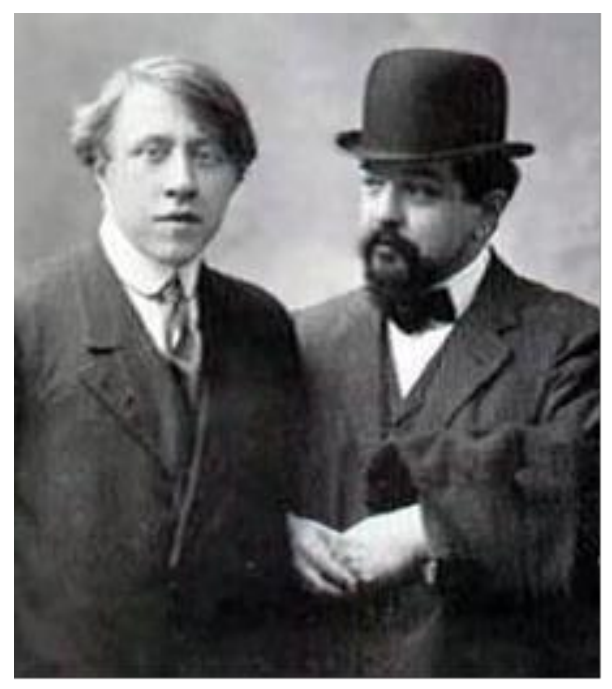

Figure 2: André Caplet, composer and conductor, and Claude Debussy, 1910.

Composers interviewed have maintained a high profile in the contemporary repertoire and have represented its most significant facets, as far as one can tell from this close view. Many have won the Pulitzer Prize for Music, but others impress the public, critics, and analysts absent that marker. While "academic" composers are interviewed, so too are independents of all stripes, Caucasian, Latino, AfricanAmerican, women and men, immigrés when they have established a resonance of their own in the United States, experimental "downtown" composers or established and more or less formal "uptown" ones, as Alex Ross (2007, p. 521) frames it in And the Rest is Noise. I chose not to interview those who seemed to me to have received Pulitzers for "standing" but who are not a force in the performed repertory- "who get heard once and get 'The Prize,"' as Joan Tower puts it.

Only four composers declined to be interviewed, and for various reasons. Many distinguished composers could not figure in the present, short report. I claim no 
encyclopedic account, but do claim that we have discovered a range of views exposing Debussy's resonance as it is generally perceived by United States composers today. Certain preoccupations with Debussy's music recur in most interviews and seem to have been formative, and I might elaborate on those now.

\section{Multi-Cultural Listening, Across and Outside the West}

Debussy for nearly all instigated multi-cultural listening. "Debussy [was]... legitimizing non-Western processes." In Philip Glass's words, "And then, here's this jackass listening to something that no one else was hearing, Asian music at that [1889] Paris World's Fair-those sounds are still in my music to this day."

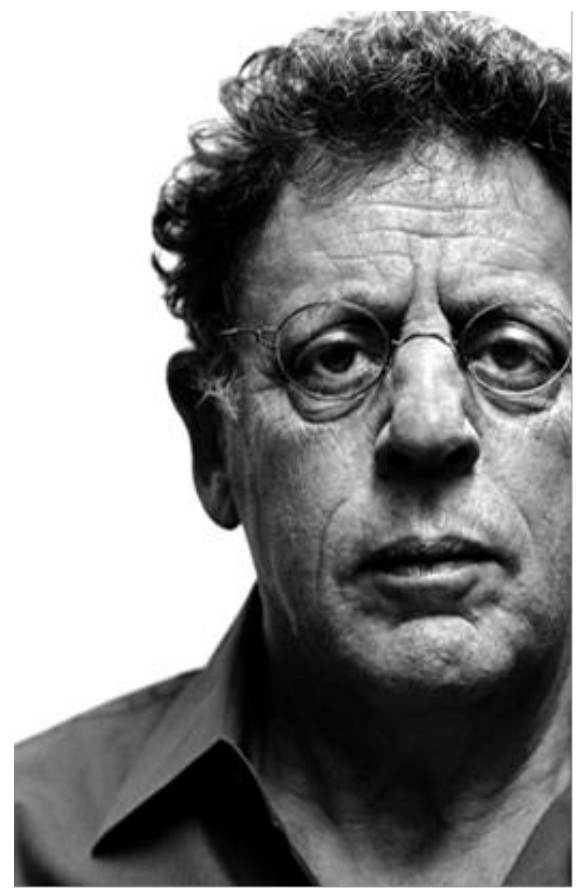

Figure 3: Philip Glass.

A notably perceptive and continual listener to Debussy, George Crumb once sat down to list the multiple cultural and artistic sources he hears in Debussy. After listing 30 sources he stopped but could have continued. As Crumb put it:

There is Balinese gamelan, French folk song, ragtime, Spanish music, Russian music that he must have learned in the Von Meck household, the French clavecinistes, medieval music, Wagner, and water and wind... but meanwhile there is a beautiful harmony... [Crumb continues excitedly] He reflected a world in his music. And yet there's a personal combination or synthesis of all these aspects that he approaches-there is Chopin, of course, but also chromaticism in its many vestiges, cabaret music, acoustical music designed with space in mind, poetry and its inspiration, nature, all have all been matters he approaches. There's no hodgepodge, but a beautiful integration. 


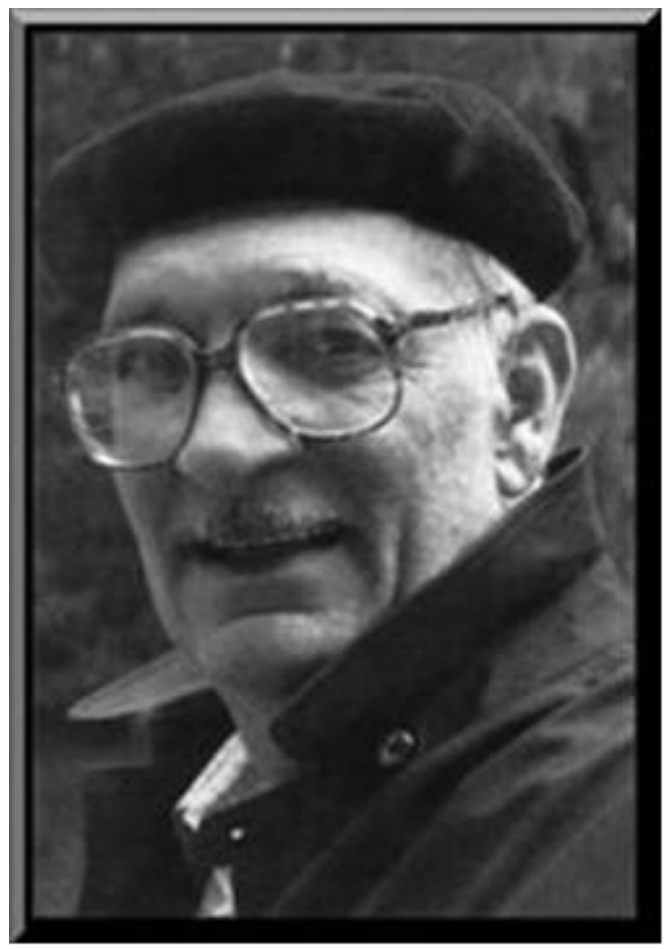

Figure 4: George Crumb.

Joseph Schwantner finds that:

Debussy was the first composer [for whom] world music was a real influence... Composers from my generation were encouraged by his experiment to engage other music than simply the canon of Western music... and that, I think, profoundly changed the way I thought about my own music. As a young composer who was very much involved with serial procedures, with the music of Webern and Schoenberg in the sixties, Debussy's insight into other music was a real revelation... a tremendous influence on many of the composers of my generation.

Indeed, many of the composers interviewed, especially those receiving advanced training in the period 1960-1975, signaled Debussy as an "escape route" from the strictures of serialist pedagogy.

\section{A Debussy Armature}

Several composers used the term Debussy's "armature," a term perhaps learned from a common composer-teacher. In question is a distinguishable set of compositional predilections, a narrative, or a frame of mind that a composer calls on, but in the modern instance is derived for each work. Composers feel they parallel Debussy and perhaps refer to him, identifying such an armature comprising sonority; an image from poetry or a natural phenomenon; and a mindset of auto-generic forming that is averse to predetermined structural formulas. Debussy, they often observe, intends structures nearly unique even when reimagining the past. They acknowledge the 
element of historicism in his music, and recognize it variously in their own depending on their relationship, I would say, to post-modernism. However, none applies that or any label to his or her "place."

Frequently sonority or timbre is mentioned as the central force in the Debussy armature. That he departs from a fixed set of predilections gains the sympathies of most composers, and an overreliance on an armature they variously call "the Debussy sound" is of course not helpful. What do composers mean when they refer to, quite frequently, "the Debussy sound." I have found that three "Debussy sounds," at times converging, are perceived. They are timbre and the movement thereof creating a dynamic of color; chord structures and movements bearing Debussy's tonal hallmark they perceive (especially tonal but added-tone chords); and chords "as objects." It is the latter to which the late Arthur Berger referred when I asked him in a discussion of 1990, "What was Debussy's most important lesson to Americans composing since mid-century?" Immediately Berger replied, "the value of the interval."

Joan Tower speaks of a "Debussy profile" and merges all three facets:

The impact was very strong on me and on many others. So I think what Austin said was absolutely true, that his impact is very far-ranging. It's because of his profile of sound, [a] kind of sensual, colorful, harmonic language that is so profound... Debussy to me is the whole chord, the whole language of the chord. That's [what gives] that sensuality and that rich harmonic movement, the action of what he's about.

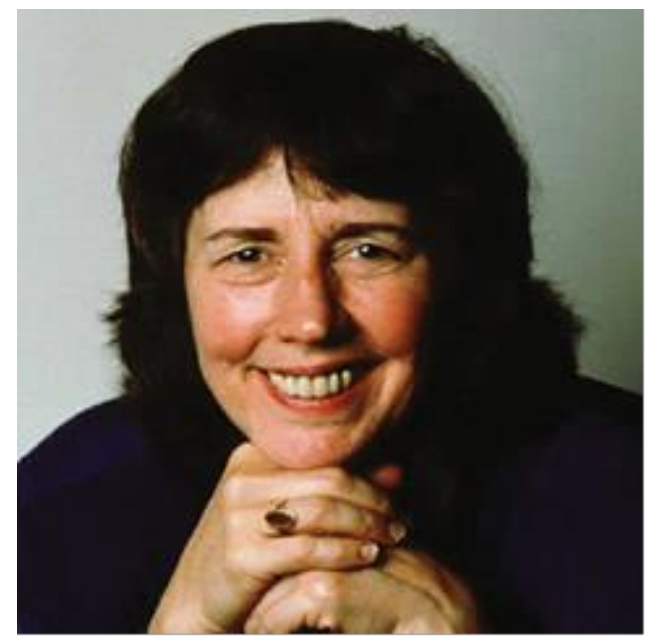

Figure 5: Joan Tower.

John Harbison found his way to a Debussy profile, a "Debussy sound," through jazz:

When I was 11 years old I [already] was a Dixieland player, and I think, at least the chord vocabulary in a lot of my music, was very strongly affected by Debussy harmony-and the phrase-making as well. The jazz presence of Debussy continues less through black musicians than white musicians such as Bill Evans, certainly, whose chord structures are very often...based not so 
much on progression but on chords as objects... That sense of chordal sonority would probably be... the most linked to Debussy I have become, in my experience.

For Harbison, that is the chord as a self-contained and constructive entity that matters.

George Crumb likewise observes Debussy's predilection for sonority as the prime mover for "how he forms leadership in the composition. Debussy's sonority is the primary conveyor of the image... sound structures convey his attitude very much as Chopin has done... they form a kind of chemistry." Crumb has read well on Debussy and cites Debussy's own use of the term "chemistry" in regard to image: "Color, timbre is the primary effect on the chemistry of a composition. If I could analyze my own music - and I can't! - I'd say that the merger and separation of color is Debussy's strongest impact."

Pauline Oliveros finds that the sheer sound of Debussy most informed her sound and philosophic world, ever changing and re-forming. Her musical experiments, as she stated:

My listening to Debussy came to a head some years ago when I encountered a deep loss and a depression. I found myself listening to La mer over and over. I don't know why I chose that piece as my mantra, but I found the sonorities self-sufficient without anything more needed. I think that piece helped set in the attraction to Deep Listening, which I've come to call the Institute with which I associate. Listen to the Sonic Meditations!

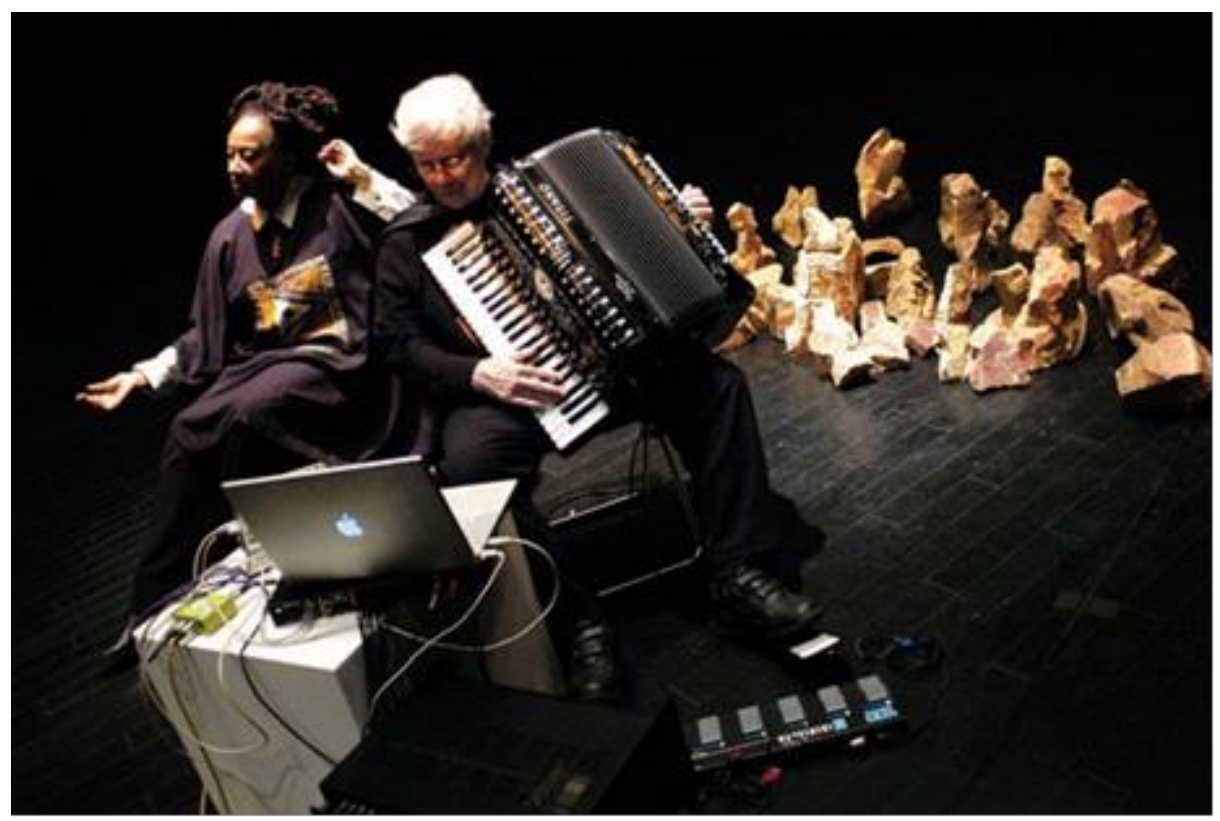

Figure 6: Pauline Oliveros (right) playing in Mexico City in 2006.

"Debussy's piano sound world captivated me from my childhood-the registral shaping, the layering, the blocks but also the linear counterpoint when he required that - these are fundamental to how I conceive of music today," according to Tania León. "When I compose away from a piano, and I've learned to do that, it's 
only because I recall how to create out of that sound world by memory!"” I think Debussy had a piano sound world."

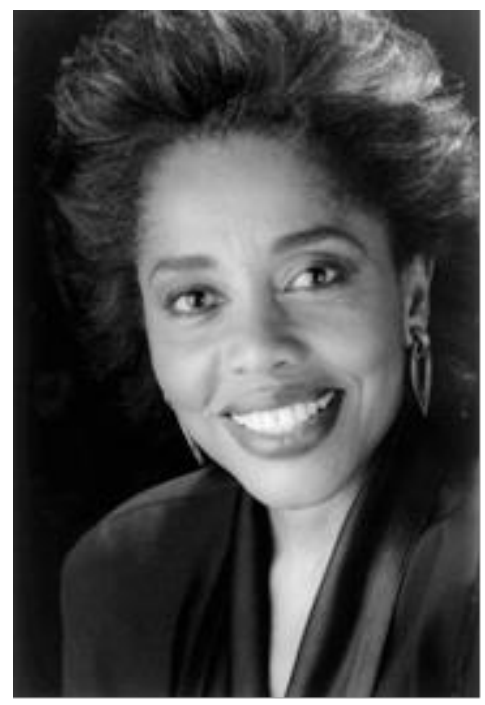

Figure 7: Tania León.

Joseph Schwantner likewise points to sonority, its tension and movement, as highly significant:

For me [Debussy's predisposition was about] instrumental color and the textural domain. For some reason, despite my credentials with dealing with 12-tone procedures and serial music, I was always struck with the central quality and the instrumental color and texture of [Debussy's] music and was attracted to that immediately. Also [I heard this Debussy effect] through composers like Messiaen, and especially a composer whom I still very much admire, Toru Takamitsu, who was certainly important [to me] as a young composer... For myself, I certainly engaged his work... in the timbral aspect of music, which has been a part and parcel of my voice as a composer... I think Jeux is... a marvelous work I always go back to and hear new sonoric riches, and that may be a cornerstone piece that I always am intrigued by. [Others are] the Chansons de Bilitis for two flutes, harp and celeste, and the flute, viola, and harp sonata.

Beyond sound in the vestiges composers hear, an image determined by poetry or nature is often cited as armature. Crumb stresses a poetic sensibility that drew him to Debussy. "All of his music impresses me as poetic. I don't know Debussy's songs very well but the instrumental music is as if songs without words. 'The cathedral is a poetic prelude." George Crumb in one of our interviews had seated himself at the piano as if instinctually, as if discussing Debussy and composing his own music at the piano were interrelated, and he demonstrated from piano and orchestral scores remarkably.

Debussy likewise impresses Joan Tower when he conceives a poetic image linked to a sonority: 
See, I think going into imagery is fine. It's therapeutic! It's maybe even useful for musicologists! [a great guffaw] And the better the image, oh my God, it's really great... I think Debussy was the best image maker, the tightest, the best ever, because the image fits the sound.

Ellen Taafe Zwilich feels that a narrative, rather than a single image, is the procedure-generating frame for Debussy, and that resonates for her:

I wouldn't say all music of the present [departs from and carries a narrative] because one of the delicious things about living in the 21st century, one of the few, is the fact that my colleagues are all so different. So I would never speak for anybody, but for me it is a narrative, whether a literal story, poem, or some image.

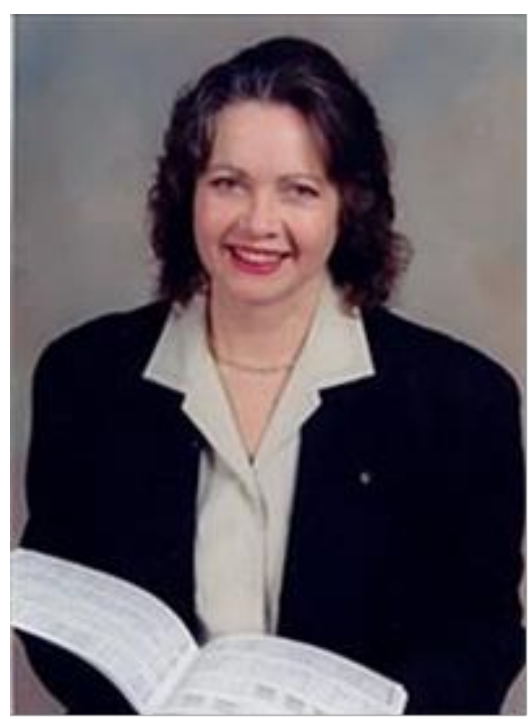

Figure 8: Ellen Taafe Zwilich.

Rather a few composers interviewed perceive a poetic armature and thereby understood that they share such a Debussy predisposition. As Joseph Schwantner explains:

For me and my music throughout my life, poetry has been a singular source of inspiration that helps... bring up that other part of my creative sensibilities. So poetic symbols, if you will, help me get excited about the musical project at hand.

William Bolcom speaks of a frame of mind, an atmosphere, and observes that he shares such impulses at times with Debussy:

In Debussy I'm constantly feeling that-always the non-Romanticism, the lack of big tuttis [sets in]. Brunnhilde doesn't wave her spear. The whole atmosphere would be so clearly non-Wagnerian... I tend to not want to give all my marbles away. 
He likewise is sensible to Debussy's humor, and says he appreciates and in ways models on it:

I feel very close to [Debussy] and Chabrier there... There's sometimes a kind of Moulin Rouge song... la la la lee dee, hah! It just glows with some kind of tipsy fun, and there's always a sense of humor even in the darkest days of Debussy. Wagner was rather short on that.

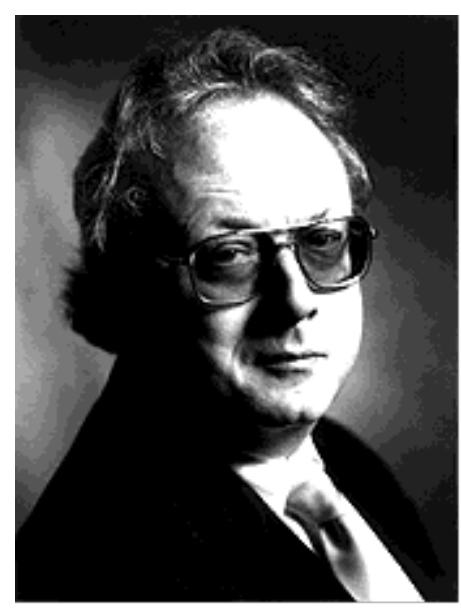

Figure 9: William Bolcom.

Bright Sheng states that he shares the Debussy predilection for:

Orientalism, the type of thing... very close to what I was trying to do. And second, there [is his abandonment of] functional harmony and [use of] harmonic substitutes. That was also very helpful [to me]. His color sensitivity has the same kind of sensitivity, you know, [as] a Chinese brush painting. I often feel that. But there is, you know, a third way of Debussy that comes from the color. I always feel that in [Debussy's] music composition [there] is a color counterpoint.

The discussion of armature turned often to intended meaning, and to Debussy as symbolist or impressionist. Composers were uninterested in the debate concerning the two mindsets, ultimately seeing them interrelated. Even when I traced the musicologists' argument, they usually replied simply that color conveyed meaning and image framed all. Schwantner understands himself as a composer of poetic imagery expressing inner workings. Like Debussy and having read well about his ideas, he recalls:

When I was young-a silly thing, I was labeled [too simply] as a kind of neoimpressionist. I also objected to this term... and don't exactly know what they had in mind. I guess because of the interest in timbre and color. But the trouble with critics is they try to simplify everything for their audience. In doing so they render their ideas useless and unintelligible as far as I can tell. 


\section{DEBUSSY'S FORMING PROCESSES}

Bolcolm hears and appears to identify with new tonal successions in Debussy: "There are always bits here and there that bring on an incredible referential situation. What do they mean, "tonally?" Debussy has enormous tonal reference. Debussy is referential like crazy." Contemporary composers explore an ever-increasing latitude for applying Debussy's perceptions, and they live up to Stravinsky's 1959 observation, when he was long ensconced in the American scene, "The musicians of my generation and I myself owe the most to Debussy" (Taruskin 1996, vol. 1, p. 309).

Steve Reich explains, regarding forming gestures in harmony, that:

In 1979-1980 I began to wonder where some of my harmonic practices were coming from historically... I was saying to myself, 'Everybody does things intuitively but they usually have some kind of historical root...' In the process of trying to trace that-particularly the idea of repeating something in the upper-middle register and then changing the bass so that it became re-harmonized without changing the melodic material. I began to realize, 'Hey, this is a rerun of The Afternoon of a Faun...' My ear had been saturated with Debussy by countless Hollywood movie composers. Music for 18 Musicians [1976], is a cycle of harmonies that would come back and return to itself...That harmonic armature... is a series of changes for jazz, too, in a sense, and [the harmonic armature] will serve as the very basis of the piece. The instrumentation is of enormous importance... The bass says, 'Hey, let's go to A,' and the soprano says. 'Well, we're already there.' Now where would you find such a chord? Well, in fact you find it in the trio in Debussy's Harp Trio [Sonata for flute, viola, and harp]. You also will find such a chord [sequencing] in Thelonious Monk...

Bright Sheng acknowledges that:

Debussy was a big influence on me... He's right, Austin. I don't think people are aware of the [Debussy contagion]... Debussy's music is shaped by a whole range of music material... He was more [of the] later-on twentieth century in his thinking... The structure is the balance of various music material. Loudness and softness, the color, and register and tempo and of course timbral choices. I think music structure is a balance of different materials... That reminds me of Debussy. So if you listen to [certain minimalism], you feel... somewhat unbalanced because it's the same thing for a long time. Or you listen to certain twentieth century music that is angry all the time, loud, and also unbalanced. I think it's a balance, it's an art of balance, that's what structure is. 


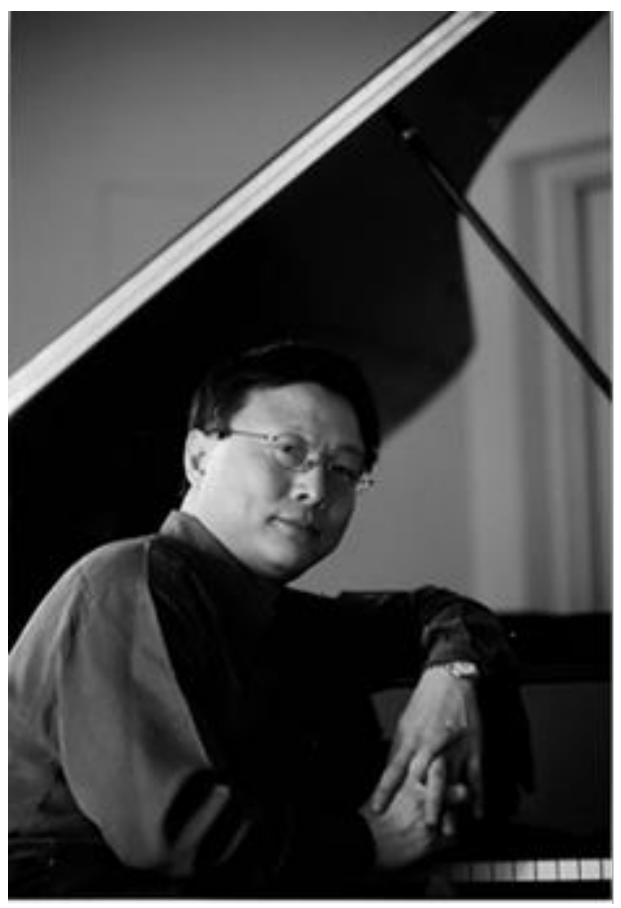

Figure 10: Bright Sheng.

Ellen Zwilich sees growth by color differentiation as an essential forming process: Timbre is an agent of form, a building block." [I had inquired into such a procedure in Symphony No. 4, The Gardens.] Zwilich continued:

I, as a matter of fact, when I write for orchestra-ever since I started, which goes back to my teenage years-I sketch on full score paper. [That way,] I have a sense of the [choices in] the pot, so to speak, this is what you have to pick from, this is what's there. It's a kick, you know, I really like [thinking in timbres]... I would say that it not only comes from Debussy, but it comes from Stravinsky and it comes from Ravel... France was the first place where a lot of this happened... The modern orchestra has a huge volume, I don't mean in dynamic level, I mean in spatial sense... Out of the Debussy tradition, my objective is for nothing that I write down to be cosmetic, [whether] it's a dynamic, if it's a mute, a kind of mute, if it's a color... I like the notion that nothing is an add-on... If you have used the harmon mute, it's because that is something that's needed at that moment. And this, I think, is something that, if it doesn't go back directly to Debussy, it certainly goes back to that era... I think it's a structural element. And it's not just color, it's weight... The colors in the Nocturnes like the English horn in "Clouds" are not like earrings. They're like a couture gown, they make the person.

Joseph Schwantner finds his methods close to Debussy's, although he might not have imagined a conscious connection upon conceiving a work: "Now that you begin to mention all of this stuff-I'm finding a closer connection with Debussy's music that I hadn't thought about, actually!" I suggested that one resemblance I hear in Schwantner's music is the reiteration of a single pitch, even if non-functional in 
harmonic terms, perhaps like the C-sharp/D-flat/C-sharp hinge in Prélude à l'après-midi d'un faune. Schwantner responded: "Yes, and I embrace that kind of sensibility all of the time in my own work harmonically and in terms of sonority."

Further on tonal processes, Schwantner finds that repeating tonal analogues occur, recalling Richard S. Parks's formulation (Parks 1989, p. 33):

I have a piece called "Sparrows" for soprano and chamber ensemble that I wrote in 1977, which was kind of an experimental piece for my moving away from serialism... And in the seemingly tonal sections, there are exactly a kind of floating tonality where the harmonies are not resolved in a kind of traditional way and yet the inference of tonality, a kind of cyclical evolving tonal scheme in those sections of that piece. They are conceived in almost a serial-like way but have this illusion of tonal inference.

Schwantner seeks simplicity of structures in his full maturity:

I've always thought about this notion of simplicity, directness. My early music was extraordinarily complex rhythmically, in terms of construction, formal, and at that global, micro level. Today, I think I use my ears more than I ever have. Debussy's idea in Footsteps in the Snow... He strikes a motive that he believes has potential... That's something that really intrigues me, that kind of integrity and the understanding of what is possible once you've finely tuned that germinal idea. That's certainly something that's always attracted me-particularly at this stage of my life. To me less is really better, and Debussy helps point me there...

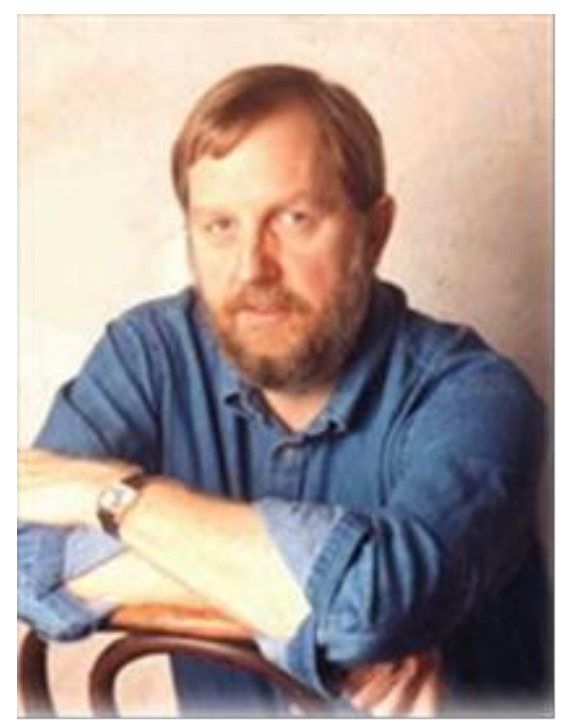

Figure 11: Joseph Schwantner.

George Crumb:

Des pas sur la neige... that is past design. His motivic use is minimalistic. The Footsteps in the Snow are based upon a very simple idea, but by way of 
harmonic and tonal manipulation Debussy is able to make that quite simple, two-note structure into the entire composition... Debussy is the most artistic of the minimalists... Debussy [is] a more convincing minimalist than many of those 'going' today.

But "minimalism" means many different things when one refers to Debussy and tries for a connection. One is reminded of the danger of reliance on labels-Joan Tower refers not to Debussy evolving an entire composition from a minimal source, as do Crumb, Schwantner and also Richard Danielpour, but Tower finds Debussy "...no sort of minimalist at all-far from it-Debussy is constantly growing and changing and creating energy."

John Harbison finds that a harmonic idea can become the germinal cell from which structures grow as he composes:

I've certainly very often based pieces based on an unattached... harmonic idea... more at the object level, and then they can either grow and multiply and make connections, or else create a vocabulary around themselves that will give them some sort of formal replacement. I often start with those harmonic stem ideas [like Debussy's]... There's a German writer who wrote an essay on... my third quartet... [she tried to analyze the harmony... but eventually she concluded that my harmonies were what she called "jazzish," which meant that in fact a lot of them are unattached tactical shapes.

I inquired into the centrality of the tone A in Harbison's violin concerto:

[Structure there is] the result of a fascination of the work of common tones. [I conceived a] very, very simple working with the whole [potential] of the common tone, but... without a [big] tonal supporting cast at all... I think that sort of legacy is, from Debussy, and the idea that relationships is not tonally revolving satellites, but a very [important] working ambiguity of just a few tones... I think a lot [about] the Afternoon of a Faun.

Although neither have read Roy Howat's book on design by proportion in Debussy (i.e. Debussy in Proportion. A Musical Analysis 1983), Richard Danielpour is impressed by Debussy's response to the Golden Mean, and Joseph Schwantner acknowledges, in his words, that Debussy "works in a calculating way that, at the same time, I believe sounds intuitive, or improvisatory." William Bolcolm hears in Debussy:

A frame, it's very good to have a frame... With him it's quite structural... Footsteps in the Snow is just that sort of piece... You certainly love taking a cell, something small like this and building it out. It must have something to do with a kind of obsessiveness. [He laughs... I admire how he] always seems to start in the same place, he goes to different places-he chases. There's a dissociation, and then he returns.

To the person, all composers interviewed are impressed by autogeneric structure in Debussy, although some composers recognize as well Debussy's reference to historic styles. Schwantner: "Now that you begin to mention all of this stuff-I'm finding 
a close connection with Debussy's music that I hadn't thought about, actually!" In similar terms, the composers frequently observed a Debussyian process of generating structures within an historic context of genre or tonality, and they perceive this as bygones of convention reborn in contemporary terms.

Wynton Marsalis states: "Debussy added another level to improvisation in jazz, a sense of flexible thematic information - a lot of space comes from a little beginning." Later Marsalis parallels his own musical impulses as a jazz musician with:

Debussy's avoidance of barren traditions that stifle music and the creation of jazz today, although it's still based on the theme and variation concept. There's a lot of Debussy reference through the piano chair [in today's jazz]. The harmony blocks of Herbie Hancock and earlier Bill Evans build the structure, and have a lot of relationships to Debussy with their impressionistic [sense], but Miles Davis, too...

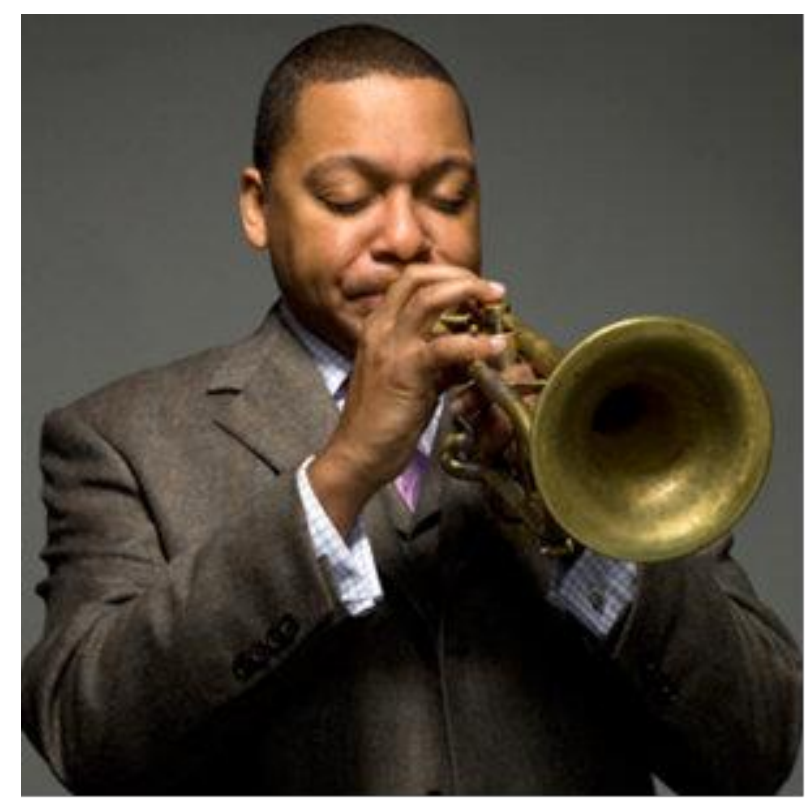

Figure 12: Wynton Marsalis.

Dave Brubeck agrees that, for Bill Evans and Bix Beiderbecke, Debussy had a main impact on harmonic layering, a trait Brubeck also learned from Debussy through Milhaud. William Bolcom states: "I always think of memory in Debussy of genre or form, the balance between structure and fantasy." 


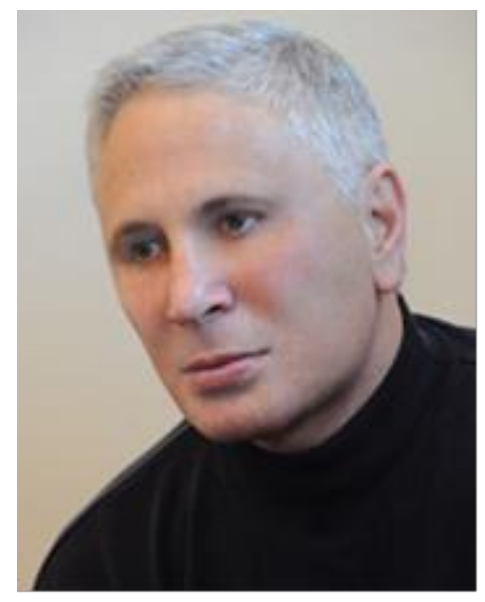

Figure 13: John Corigliano.

However, John Corigliano hears less of expected forming but is moved by Debussy's seemingly conscious rejections:

Whatever gave him pleasure! The logic is $\mathrm{A}+\mathrm{B}=\mathrm{C}$, and he knew that, but he thought, 'I will not present C!' George Crumb hears Debussy as "archeological - he approaches many "found" idioms as a child would, digging and discovering. And yet, there is no pure whimsy, there is a structure, albeit arrived at intuitively.

Joan Tower is aware of how:

With Debussy, [he's] tasting wines when he writes. Everything has to have a taste. He will not write a note down without having a particular garlic, or whatever herb... His music is timbral [at the generation of the idea]. [...] My music is very much like Debussy's in the sense that, if I write it at the piano, which I do, I'm very much involved with register, color, and then I get the intensity going in this or that register.

John Harbison observes: "A really weird sort of climaxes, less level in pieces by American contemporaries. I think they must have been very aware of Debussy, because he begins to lose the urge to make a hierarchy of the form."

Crumb stresses that Debussy's "adaptation of the past is never superficial," and he points to La cathédrale engloutie:

The entire work is organic; it is altogether subsumed within the mode of water. The whole system is fleshed out in the terms of the core gesture. Only listen to the Faun to see how a simple, really childlike gesture at the first two or three measures... becomes the whole piece. Only Musorgsky and [the Spanish poet] Lorca could do that, could turn themselves into a child, could de-sophisticate [themselves] such as Debussy did and draw a work out of such simplicity. That never ceases to impress me. 


\section{Musical Resonances Wagnerian, Schoenbergian, and Stravinskyan}

Debussy permits a kaleidoscope of directions and, to composers, suggests individual solutions not bound by dogma or routine. It is essential to note that, while the composers were quite serious about the important Debussy resonance, only relatively few moved into a rhetoric of Debussy as an exclusive force. They were however ready to contrast his bearing with those of Wagner (via the evolution of the Second Viennese School), Schoenberg, and Stravinsky. Composers nearly all stated outright that their pathway has passed Schoenberg, even when most of these were schooled in serialism in the composing academies of the 1960's and 1970's.

Steve Reich:

[The Schoenberg tradition] is thankfully mostly gone, but there are a few diehards especially in the universities, of course. But I think, as a viable mode, the French tradition has triumphed today because basically younger composers in their 50's, 40's, 30' and 20's have picked up what I was doing, and what Terry Riley was doing, what Phil Glass was doing... and they have now gone on in their own direction from there, which means they are in a sense children of the French, what you could say is a third generation of French impressionism. The way of thinking is restored —of all places!-in America.

Reich continues:

You don't feel the ghost of Wagner leaning on your shoulder... you feel the presence of Debussy and Ravel... So the French connection runs deep. With the exception of Charles Ives, who is really more Germanically oriented, actually, it seems to me, our most important, most famous (historically) American composers come out of the French tradition... I know I've heard people say, 'Oh, Charlie Parker has heard Debussy...' I think bebop in general is definitely somehow a cousin of French impressionism.

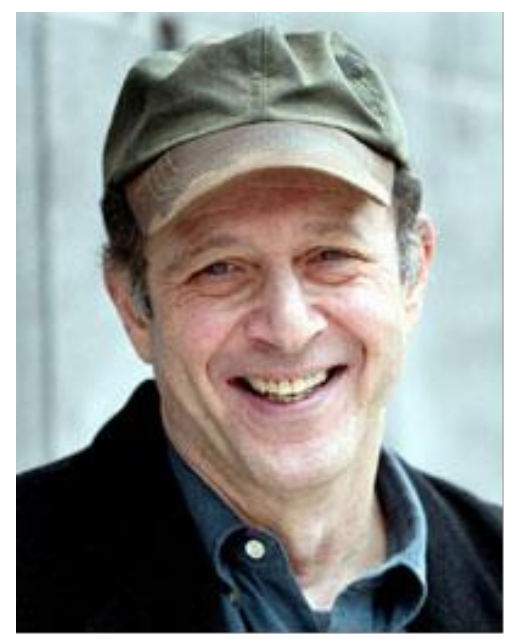

Figure 14: Steve Reich. 
The address to audiences preferred by several composers is "Debussyan," as Tower expresses effusively:

Debussy is a sharer, in fact he's an emotional sharer. I listen to music actually from one point of view: does this composer want me involved in their intimate feelings, their intimate feelings about color or motion, or do they want to keep me kind of at a distance? [...] I don't really admire Schoenberg anymore, I don't like him. I think he definitely distances himself from you! He says, uh, I don't like crowds... But Debussy is like, 'Ah, you know, come here, you have to listen, you have to taste this chord. It's so magnificent.' And he's inviting you in on every possible level... I love him for that. I'll go with him-I'm so excited-he'll lead me right down the path! [she laughs hardily]

Crumb as well comments on the serial idea and its continuing relevance to composers:

Of course you remember that Schoenberg made an arrangement of the Faun and showed some sensibility, but he doesn't hit me with a particular power. Webern's timbral sense appealed to me even more than his structural side. Berg, still, his transcendentalism and his humanity, his spirituality spoke to me. Schoenberg, late in life, had a second life experience, a life after death experience, and he regained spirituality and a more human music. Even so, Schoenberg seems to be more of a person of struggle - a struggle between tedium and mechanisms against a spiritual sense.

Stravinsky seems to be waning among United States composers today as a source for new direction. On Stravinsky, George Crumb indicates: "For me the primary sources are Debussy, Mahler, Bartók, and Ives... Stravinsky's neoclassic stuff loses me. I can't understand all that florid to-do over OEdipus. The Greeks didn't act that way!" But Crumb, unfailingly open, goes on to say that he enjoys Stravinsky, more or less, despite his mannerisms. Ellen Taafe Zwilich likewise perceives a greater Debussy presence: "I think Jeux is one of the most interesting pieces of the early 20th century. I find...that when the historical narrative is broadened, it will probably be seen as much more important than the Rite of Spring."

\section{Debussy's Permission, Debussy's Structure}

John Harbison notes that:

The aesthetic freedom, which is very much in the air in recent years, is very congenial to Ives, [but that] sanction also comes from Debussy. So many premises are conceivable in the last twenty years when, prior to that, you could say that there was much less latitude of, sort of, what might be a ground for fruitful composition. And I think that the appreciation of composers who state that [aesthetic freedom] is at a high water mark, they're right on... You know, [earlier] you could talk to Europeans about American music and 
they would say we only are interested in tinkering with the slightly lunatic aspect of American music, with... Ives and composers that they perceived to be, in some sense, amateurs. I think they liked to think of the Americans as amateurs in art. But strangely enough, when I heard the Europeans take to Toscanini and his Debussy, I felt they were more willing to engage with what I would take to be the irrational element in Debussy's thought. Jeux, for instance is a case in point-I keep going back to it because it is really striking and startling... a free association kind of thing. Toscanini... was kind of half-crazy in what he did. I mean, what he did in La mer, it was out of control. Strangely, I think Debussy benefits from that near wildness because free performance underscores free form.

However, on the side of structure, Joseph Schwantner finds Debussy "giving permission for a breadth of different syntheses, nowadays including rock and popular music." Concerning Debussy's model of open possibilities, but also as a force for structural cohesion, I proposed that Debussy resonates today. Schwantner responded enthusiastically: "Oh, I think so. I think you're right about that. There's no question about that. That's absolutely true."

As Ellen Zwilich put it:

I guess I understand [what] Ned Rorem always says, that music's either French or German. But I want to be both, I want to take in everything that's out there, whether it's French, German, Russian, Chinese, you know. All of these, I want it all and without being terribly self-conscious about what comes out when I write.

But moreover, Joan Tower speaks of her disinclination to follow a model literally, and her strong tendency consciously to shut out a threatening imposition:

I dedicated a piece to Beethoven and another to Messiaen... And there are others, Shostakovich and Debussy and Copland, to name a few. But when I sit down to write a piece of music, I can't be thinking about these composers. In fact if I think about them, I chase them out!... I'm trying to do my own little garden, here. And in order to really get that garden to sit up, I have to make sure that I'm looking very carefully at that, and I'm not saying, well, Beethoven would have done it this way, or Debussy would have done it this way, or Monk would have done it this way. I can't do that, I have to concentrate on this flower coming up right here, and that's a problem that all composers have, and they have to find a reasonable solution of their own.

Thus, while Debussy resonates in their music, his notable disinclination to insert himself as an outright model, and his continual self-reinvention, is everywhere admired. But so too is the rightness of his structures to the narrative, image, or abstraction he desires. Crumb, again:

Each work dictates its own choices for Debussy, and he leaves that to the rest of us, too. That impressed me early on, that Debussy's style was free and was 
able to make strong cross-referrals on its on. There's no pure whimsy, there's a structure, albeit arrived at intuitively.

John Corigliano on Debussy and post-modernism and on a converged dichotomy: "I do think we have gone past modernism, and today's young composers, not unlike Debussy and maybe even remembering him, in America are in a healthy option." Summing up his own cognizance of the past and reluctance to assert an agenda, George Crumb again refers to Debussy:

I have never reinvented music as perhaps others have, nor do I think Debussy intended to reinvent music... The minimalist idea can be taken in many directions. Modernism is false and there is nothing new under the sun, ultimately. The psychological and the spiritual direction is the one with which I feel the greatest contact. Mahler projects that fully. Debussy, likewise, projects the psychological and even the spiritual into the future. Debussy is quite modern but not 'modernist.' Never agenda-ed!

Acknowledging the continuing Debussy resonance once she approaches the possibility consciously, Ellen Taafe Zwilich states:

You know, before you called me about this interview, I would never have said... when people ask about my influences, I always say something totally evasive, like, I don't even really quite know or even care. I would not have thought of Debussy as being important to me, but I have a feeling you may be right... I would not be unhappy at all in the Debussy idea that nothing is cosmetic, including color, and weight of orchestral sound, and distribution, and geography of sound, these are terribly important to me... I'd be thrilled to think it came from Debussy. Thank you! [she blows a kiss]

And finally, Philip Glass can summarize the continuing presence he and virtually all other contemporaries perceive, suggested by the quotation from Glass as this essay begins. There is an awareness among composers nowadays that Debussy is the early-century composer most suggestive, but not necessarily provocative, for "the grandchildren of the 20th century." Glass: "I saw that famous picture of Debussy standing next to Stravinsky, and I said, 'Oh, there they are,' but without any hesitation I pointed to Debussy and said, 'He was the one.'” 


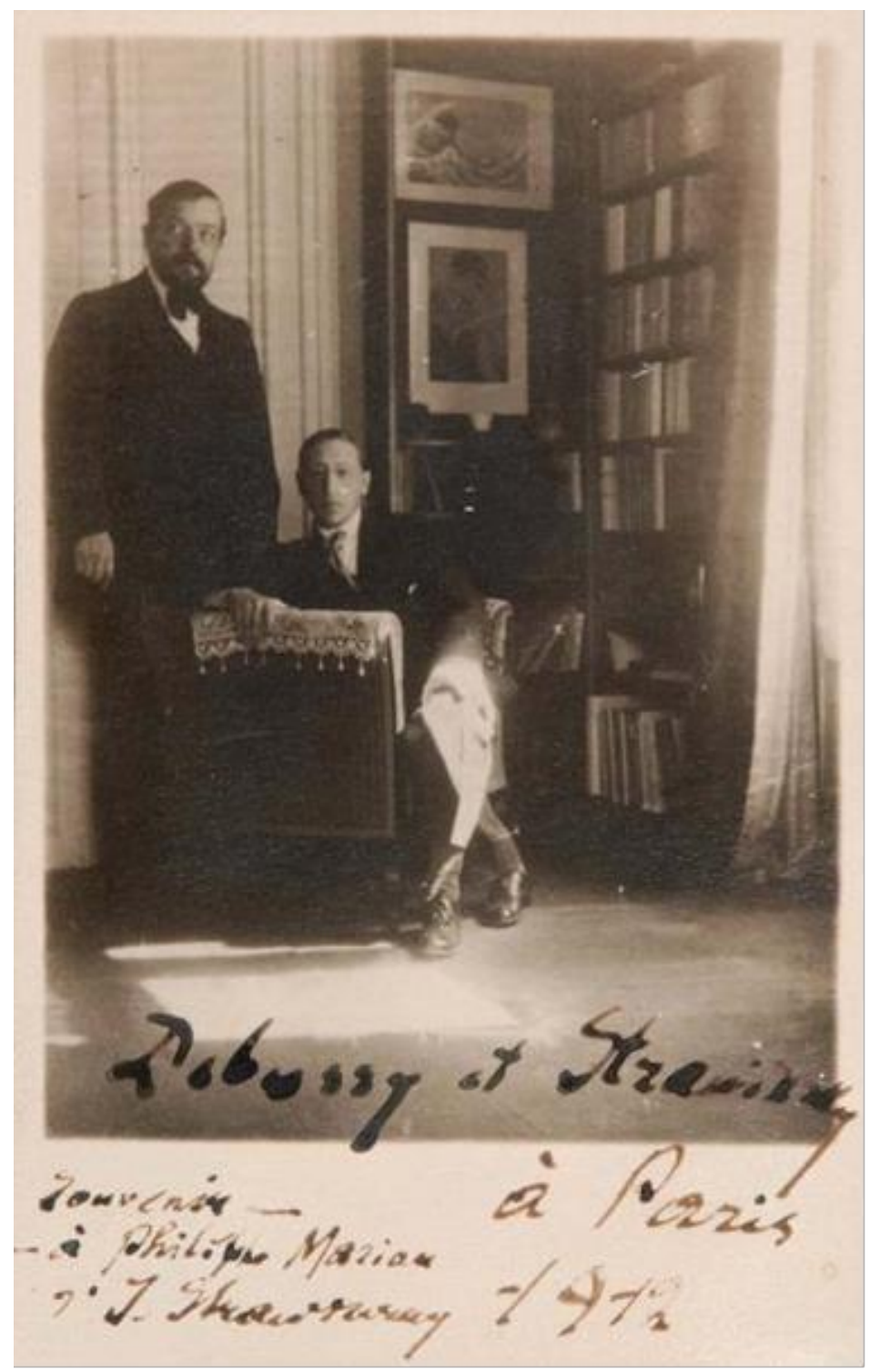

Figure 15: Debussy and Stravinsky, photo 1912.

\section{BIBLIOGRAPHY}

Austin, William W. (1966), Music of the 20th Century. From Debussy Through Stravinsky, New York/ London, Norton/Dent.

Borroff, Edith (1986), Three American Composers [Crumb, Irwin Fischer, Ross Lee Finney], Manham, Maryland, University Press of America.

The Boston Transcript, 21 October 1908.

Botstein, Leon (2013), "Modernism," Grove Music Online. Oxford Music Online, Oxford University Press, http://www.oxfordmusiconline.com/subscriber/article/grove/music/40625, accessed September 24, 2013.

Briscoe, James (2010), “'Earthian Music.' Tania León and Her Compositional Arc of Cultures," 2009 International Conference on the Arts in Society, Venice Biennale, Venice, Italy, published in International Journal of the Arts in Society, vol. 4, n 6, p. 193-212. 
Forte, Allen (1992), "Generative Processes in a Debussy Prelude," in Claude Palisca, Nancy Kovaleff Baker and Barbara Russano Hanning (ed.), Musical Humanism and its Legacy. Essays in Honor of Claude V. Palisca, Hillsdale, New York, Pendragon Press, p. 471-486.

Glass, Ira (1999), "An Interview with Composer Philip Glass," transcription, New York, NPR "This American Life."

Harbison, John (1985), "Six Tanglewood Talks (1,2,3)," Perspectives of New Music, vol. 23, n 2, p. 12 22.

Harbison, John (1985), "Six Tanglewood Talks (4,5,6)," Perspectives of New Music, vol. 24, no 1, p. 4660.

Harbison, John (1992), "Symmetries and the New Tonality," Contemporary Music Review, vol. 6, n 2, p. 71-79.

Howat, Roy (1983), Debussy in Proportion. A Musical Analysis, Cambridge/New York, Cambridge University Press.

Kostelanetz, Richard, and Robert Flemming (ed.) (1997), Writings on Glass. Essays, Interviews, Criticism, New York, Schirmer Books.

Kramer, Lawrence (ed.) (2000), Walt Whitman and Musical Modernism, New York, Garland Publishing.

Oliveros, Pauline (2005), Deep Listening. A Composer's Sound Practice, New York, iUniverse, Inc.

Ott, David L. (1983), "The Role of Texture and Timbre in the Music of George Crumb," Doctoral Thesis, University of Kentucky.

Parker, Craig B. (2004), "Ellen Taaffe Zwilich," in James R.Briscoe (ed.), New Historical Anthology of Music by Women, Bloomington/Indianapolis, Indiana University Press, p. 467-470.

Parks, Richard S. (1989), "Tonal Analogues as Atonal Resources and Their Relation to Form in Debussy's Chromatic Etude," Journal of Music Theory, vol. 29, n 1, p. 33-60. Further see Richard S. Parks (1989), The Music of Claude Debussy, New Haven/London, Yale University Press.

Perlis, Vivian, and Libby van Cleve (1998), Composers' Voices from Ives to Ellington, oral history of American music, extended to include interviews with John Harbison and Tania León (among others), New Haven, Yale University Press, various.

Riis, Thomas L. (1993), "A Conversation with George Crumb," American Music Research Center Journal, vol. 3, p. 40-49.

Ross, Alex (2007), And the Rest is Noise, New York, Farrar, Straus and Giroux.

Schwartz, Elliott, and Daniel Godfrey (1993), Music Since 1945. Issues, Materials, and Literature, New York, Schirmer.

Smith, Geoff, and Nicola Walker Smith (1995), In New Voices. American Composers Talk About Their Music, Portland, OR, Amadeus Press, p. 93-102.

Strickland, Edward (1991), American Composers. Dialogues on Contemporary Music, Bloomington/ Indianapolis, Indiana University Press.

Stucky, Steven (2010), "Music without Borders," program notes, the Winnipeg New Music Festival, "Breaking New Ground," Feb. 6-10, http://www.newmusicfestival.ca/wp/?page id=75, accessed September 24, 2013.

Taruskin, Richard (2005), "After Everything," The Oxford History of Western Music, vol. 5, Oxford, Oxford University Press, p. 411-472.

Richard Taruskin (1996), Stravinsky and the Russian Traditions. A Biography of the Works Through Mavra, vol. 1, Berkele, University of California Press.

Thomas, Gavin (2010), Composition Today. Elliott Carter: An Interview and Survey of Works, The Rough Guide to Classical Music, New York, Penguin Group.

Thomas, Jennifer (1981), "The Use of Color in Three Chamber Works of the 20th Century," Indiana Theory Review, vol. 4, n 3, p. 22-40 (Webern, Crumb, Stravinsky). 
Thomson, Virgil (1950), The Piano Works of Claude Debussy, foreword to Robert Schmitz, New York, Duell, Sloan, and Pearce.

Sutton, Daniel (1993), “The Musical Language of George Crumb's Makrokosmos Volume II, and Its Relationship to the Style of Claude Debussy," D.M.A. thesis, Manhattan School of Music. 